\title{
An Urban-Spatial Analysis of the Women in the Informal Sectors of Greater Guwahati City of Assam, India
}

\author{
Zona Bhuyan $^{+}$
}

\section{Abstract}

This article reflects the use of urban space by women in urban informal sectors in the city of Guwahati located in North East India. The population influx from across the borders in the aftermath of the partition has huge implications both on polity and on economy of the northeastern states in general and Assam in particular. Importantly, the urban informal sectors have a sizeable share in terms of its significant contributions towards Gross Domestic Product (GDP) as well as generation of employment opportunities largely. Using a feminist perspective, the research is an attempt to investigate the engagement of women in the informal sector in greater Guwahati. Research findings reveal that the occupations of the women workers are location-specific, that is, the manufacturing sectors (textiles, food preparation, printing and skilled service) are mainly home/shop based production (fixed locations) whereas the service sectors (leisure, caring, elementary construction, elementary sales and cleaning occupation) operate at variable locations (construction sites, street pavements, marketplaces and other various locations). Further analysis shows that the informal sector is highly demand dependent and such demands are in the central business areas of the city, therefore informal sector services (skilled services and elementary services) are found to be located in and around the central areas of Guwahati city. Women operators in the informal sector are attracted to the central business district because of the many advantages that it enjoys relative to other parts of a city. The paper concludes by calling on policy makers and physical planning agencies to evolve more pragmatic strategies for urban development matters in order that urban informal sector activities can be integrated into urban development plans. Finally, further research is called for on how urban planners could redesign the urban space with appropriate consideration of the informal sector operators.

Key Words: Urban Informal Sector, Location, Guwahati, Women, Spatial, Occupation

\footnotetext{
${ }^{\dagger}$ Research Scholar, Department of Geography, North-Eastern Hill University, Shillong - 793022, [Email: zbhuyan@gmail.com]

(c) 2013 Bhuyan. This is an Open Access article distributed under the terms of the Creative Commons Attribution License (http://creativecommons.org/licenses/by/2.0), which permits unrestricted use, distribution, and reproduction in any medium, provided the original work is properly cited.
} 


\section{Introduction}

The informal sector has over the years, assumed centre stage in the writings of many authors interested in understanding the survival strategies of marginalised and vulnerable groups, particularly developing countries (Mitullah and Wachira, 1997; Mupedziswa and Gumbo, 1998; Roy and AlSayyad, 2004; Unni and Rani, 2000; Williams and Gurtoo, 2011). Various attempts have been made to theorise this sector and many of these writings have emphasised the common situation of informal sector operators, which are uniform conditions and outcomes (Bhatt, 2006; Unni and Rani, 2000; Williams and Gurtoo, 2011).

Gender studies relating to the urban informal services are inherent in analysis pertaining to the workforce pattern and distribution of women workers engaged in unorganised or informal sectors. Therefore, central to the entire debates of the 'informal sector' is that, in India, 94\% of total workforce (Shram Shakti, 1988; Williams and Gurtoo, 2011) is engaged in this sector, which bears very little formal space, unless planned otherwise. In the said context, a large number of studies have explored the gendered dimensions of informalisation of the Indian economy (Bhatt, 2006; Unni and Rani, 2000; Williams and Gurtoo, 2011). However, far too little attention has been paid to investigate the spatial dimension of women engaged in the informal sectors of Assam. Given the population influx from across the borders in the aftermath of the partition (1947) has huge implications both on polity and on economy of the northeastern states in general and Assam in particular. The key purpose of this research is then, to investigate the spatial distribution of urban informal sectors and engagement of women in this sector in particular, in the city of Guwahati located in North East India. For this, the research uses a feminist perspective to examine as to how women participate in this sector of the economy. The article begins by a brief discussion of the meaning of the concept of 'informal sector' and its growing complexity in an urban setting.

\section{Meaning and understanding of the informal sector and its complexities}

The meaning of the term 'informal sector' has remained somewhat ambiguous despite a large number of research studies in recent times (Armstrong and McGee, 1987; Bivens and Sarah, 2004; Perera, 1994; Quijano-Obregon, 1974; Mathew, 1989; Mazumdar, 1976; Mitullah and Wachira, 1997; Nelson, 1988; Nwaka, 2005; Sethuraman, 1981; Todaro, 1969; Young, 1981). The concept of the 'informal sector', was introduced into international usage in 1972 by the International Labour Organization (ILO) in its classic Kenya Mission Report that defined 'informal' as a "...way of doing things characterised by - ease of entry and exit; reliance on indigenous resources; family ownership; small scale operations; labour intensive and adaptive technology; skills acquired outside of the formal sector; and unregulated and competitive markets" (ILO, 1972). Since that time, different authors (and the ILO itself) have introduced many different definitions. A recent ILO report uses the term 'informal sector' to describe a "...range of economic units in urban areas which are largely owned and operated by single individuals with little capital and labour, and which produce and distribute goods and services with a view to generating income and employment to the persons concerned (ILO 1997: World Employment Report, Geneva).

However, the nature, speed, and scale of urbanisation processes in cities of the global south, together with resource shortages, make the task of managing the collective affairs of urban regions ever more complex, adding new challenges to urban governance. In 2007, it was recognised that regions in the south have had the greatest changes in rates of urbanisation over time. Due to geopolitical changes and their accompanying economic and social changes, city centre areas are the most vulnerable urban spaces (Branea, 2011). In similar context, Watson (2011) opined that planning regulations are frequently so onerous that the poor are obliged to step outside the requirements of the law, living and working in 
ways that are categorised as "informal" and are, therefore, open to state-initiated censure and often-repressive intervention. She further stated that often planners are educated and encouraged (by prevailing legislation) to fulfil a function in cities that is predominantly about control. This negatively affects the livelihoods and shelter options of the urban poor and serves formal economic interests, resulting in urban environments that exclude both socially and spatially.

Informal trading comprises a major part of the informal sector in third-world economies, and employs a substantial proportion of the urban poor. However, the transformation of the urban environment whereby central streets and squares are increasingly cleansed of informal trading activities is putting pressure on informal traders. New spatial patterns of trading are adapting to the new policing of public space and different traders are developing different strategies of survival in the changing circumstances (Bromley, 2009).

Informality at first glance seems to be a land use problem, and it is thus often managed through attempts to restore "order" to the urban landscape, or to bring it into the fold of formal markets. The limitations of urban upgrading policies reflect the limitations of the ideology of space. In such policy approaches, what is redeveloped is space-the built environment and physical amenities-and the search for rational order is framed in aesthetic terms, via a belief that an efficient city is one that looks regimented and orderly in a geometrical sense, rather than one that truly enhances people's capacities or livelihoods (Roy, 2005).

In order to achieve optimal integration of business opportunities in low-income residential developments, while avoiding the perpetration of aesthetically offensive alterations, urban planners and other professionals in environmental management need to incorporate the processes of the informal economy into their designs. Hence, Branea (2011: 24) argues that "Our role, as shapers of space, should be one of continuous harmonization of imbalance between these two elements: on one hand, the perception of informal spaces as unplannable; and on the other, the desire to improve and integrate such informal spaces. Whatever the role we choose to play, the spatial planners take the lead". In this context, this research has important implications on policy makers and planning agencies to evolve more sensible and business like strategies for urban development matters so that urban informal sector activities can be integrated into urban development plans.

Understanding of the informal sector is more often associated with the dichotomy between the formal and the informal sectors. However, the dichotomy of the formal and informal sectors often ignores the importance of the informal sectors with respect to urban spaces. The informal sectors are often marginalised in the urban spaces, even though the informal sectors play a major contribution to the urban employment.

In their book, Urban Informality: Transnational perspectives from the Middle East, South Asia and Latin America, Ananya Roy and Nezar AlSayyad (2004) introduced the concept of informal urban areas as the logic that explains the process of urban transformation. They did not emphasise on the dichotomy of the formal and the informal sectors but on the understanding that the informal sector is a part of the economic structure of society.

Notwithstanding, women remain concentrated in "invisible" areas of informal work, such as domestic labour, piece-rate homework, and assistance in small family enterprises, which offer precarious employment status, low, irregular or no remuneration, little or no access to social security or protection, and limited ability to organise to ensure the enforcement of international labour standards and human rights (Abramo and Valenzuela, 2006; Carr and Chen, 2002; Fernández-Pacheco, 2003a, b; Vega Gramunt, 2004). Therefore, the following section uses feminist perspectives as lenses to examine the occupation the women of my 
study area are engaged in the informal sector, distance travelled by these women to their workplaces and their modes of travel.

\section{Women in the informal sector through feminist geography lens}

Feminist geography continues to make an impact on human geography since its inception in the mid-1970s. It contributes to the increasing understanding of the gendered nature of economic processes through the study of spatial dimension to practice theories important for understanding the gendered relationship between individual consciousness, action, and social change. Hence, McDowell (1992) argues that feminist research is sensitive to power relations and their influence on the process of research has become central to feminist analysis and thoughts.

In her book, Woman's Role in Economic Development, Ester Boserup (1970), first developed a systematic insight to the gendered effects of industrialisation, agricultural changes and other associated structural transformation and identified women's role as both producers and workers. Indeed, she was the pioneer of Women in Development (WID) approach (Bhattacharyya Sarma, 2009). She placed the importance of women's role in agricultural economies by highlighting that in most agrarian economies, women not only contributed more than $50 \%$ of the agricultural work but also played key roles in trade. However, there were very few researches that focussed on women's engagement and the problems they face in the labour market (Boserup, 1970). Taking the WID framework, this research is an attempt to highlight women's engagement in the informal economy of greater Guwahati area.

Feminist economists continue to challenge the notions of 'work', 'workforce' and, 'employment' and argue that all three carries different meanings in different contexts. They attacked the narrowly defined notion of 'paid work' (employment), which is based largely on production or manufacture of goods and services for the market, portrays the 'unpaid' domestic work and childcare activities as invisible (Olsen, 1978; see also, (Bhattacharyya Sarma, 2009), thereby, these unpaid women's activities remain unrecognised and undervalued, which highlight women's inequality at home, workplace and society as a whole and push women to a marginalised position. Alongside, the feminists focussed (and continue to focus) on occupational segregation (Hakim, 1996), economics of care, reconstruction of economic models of development and gender inclusive approaches to data collection. Taking all these indicators on board, the Human Development Report $(1995)^{1}$, introduced two new measures: Gender Empowerment Measure (GEM) and the Gender-related Development Index (GDI), aimed at adding a gender-sensitive dimension to the Human Development Index. Importantly, Chapter 4 of this report devoted to valuing women's work. The report analysed the undervaluation and non-recognition of women's work and offered five-point strategy in gaining gender equality: constitutional equality between the sexes in a defined period, revamping of economic and institutional arrangements to extend more choices to women and men in the work place, universalisation of female education, improved reproductive health and more credit for women, and greater political and economic opportunities for women.

Clearly, the highly charged debates emerged on androcentric biases in economic geography research. Feminist geographers, Monk and Hanson (1982) argues that traditional economic geography research fails to account for women's experiences in studies of migration, travel patterns, employment trends, and livelihood strategies and therefore, urges the researchers to strive for impartial, neutral and value-free research.

Since the World War II, there has been a considerable rise in women's employment across the globe. However, the economic

\footnotetext{
${ }^{1}$ Human Development Report 1995: Gender and Human Development, http://hdr.undp.org/en/reports/global/hdr1995/ (accessed April 15, 2013)
} 
growth and development remain highly uneven. According to the Global Employment Trends for Women $(2012)^{2}$, preliminary estimates of female employment-to-population ratio stands at $47.8 \%$, while male employmentto-population ratio is $72.7 \%$. The report states that the global gender gap in employment has worsened due to the on-going economic downturn. Nevertheless, women's continuous increase in numbers in global labour markets is commonly referred to as the feminisation of the labour force (Standing, 1999; see also BhattacharyyaSarma, 2009 and Unni and Rani, 2000). However, the feminisation of the labour force in developing economies differs from that observed in developed economies (Standing, 1999; BhattacharyyaSarma, 2009). For instance, in developing economies, feminisation is associated with a process of proletarianization, whereby the majority of women's labour, is absorbed into the informal sector. This is evident in the deregulation of labour markets, a fragmentation of production processes, and the creation of new areas of export orientation that demand casual (less secure), low skill, informal contracts, and ultimately low pay for most female workers (Bhattacharyya Sarma, 2009).

In 1995, Hanson and Pratt examined a number of studies that focussed on the construction of social boundaries between women and men and women living over different geographical space. They focussed on work and occupational segregation of men and women. In doing so, they sought to draw on the significance of local variations in women's work experiences and commuting patterns to the place of work. Earlier, Momsen (1991) argued that in many developing countries, large percentage of women work in the informal sector of the labour market. However, they are paid but their works remain unrecognised and hence, do not enter into the official statistics of

\footnotetext{
${ }^{2}$ Global Employment Trends for Women (2012)., International Labour Organisation, http://www.ilo.org/wcmsp5/groups/public/--dgreports/--dcomm/documents/publication/wcms_195447.pdf (accessed April, 15, 2013)
}

employment. However, recent studies show that the ever-growing expansion of the informal sector is being recognised in the new global economy (Charmes, 2009; Williams and Gurtoo, 2011). Importantly, the ILO estimates of 2002 uncovered that in India, $60 \%$ of the Net Domestic Product and $68 \%$ of the total income earned by the workforce are generated from the informal sectors (see also, Wiliams and Gurtoo, 2011). Most importantly, the National Sample Survey 2005 revealed that women comprises approximately $33 \%$ of the informal sector workforce but contributes $20 \%$ of the country's GDP. Hence, these women collectively act as active agents of economic change. This research however seeks spatial explanation by analysing women's engagement in the urban informal sectors of Guwahati. In the next section, I outline a brief overview of the study area.

\section{Background of the Study Area}

Guwahati is the premier city of Assam, the largest metropolitan city of North East India and one of the rapidly growing cities in India. It is said to be the gateway of the North East Region of India. Guwahati lies on the crescentshaped, alluvial southern bank of the river Brahmaputra in Kamrup Metro District of Assam with its cardinal points as $26^{0} 10^{\prime}$ north latitude and $92^{\circ} 49^{\prime}$ east longitude. Dispur, the capital of the state of Assam is situated on the periphery of the city and is the seat of the Government of Assam.

With the establishment of Guwahati refinery in 1962, the construction of bridge over the river Brahmaputra at Saraighat and the shifting of capital from Shillong to Guwahati in 1972 marked the beginning of industrialisation in the city as well as made tremendous economic impact on the city and turned Guwahati into one of the most important cities in the North Eastern Region of India.

During the past few decades, it has experienced unprecedented spatial expansion and a steep rise in population with noticeable increase in density and transformation of socio-economic setting. At present, Guwahati alone constitutes 
almost $25 \%$ of the state's total urban population. The exponential increase in population and unplanned growth over the years have created enormous pressure on the availability of land and infrastructure with the result that the city is severely stressed in terms of available infrastructure and delivery of basic services. In spite of pressure on land, the informal sector enterprises thrive, as best as they can, by accommodating themselves strategically near work centres, commercial areas, outside the boundaries of schools, colleges and hospitals, transport modes, near large housing clusters or at the home of the informal sector owners (GMDA, 2010).

In land scarce cities like Guwahati, accommodating informal sector in economically advantageous locations is an extremely difficult task. Lack of suitable accommodation is a major reason why informal sector operators appropriate their operational base, which is unutilised, underutilised or abandoned land and premises, which exist in and around the central urban areas due to outdated or defunct uses to lower their operational costs of their units. "Therefore, providing informal sector that have considerable potential to redevelop for new urban functions with a fair share of the urban space would be an effective production and marketing assistance strategy" (Sethuraman, $1981: 173)$.

\section{Methodology}

A survey was conducted during October 2008April 2009 across 500 respondents on a purposive sampling basis, consisting primarily of women engaged in the various urban informal sector activities. The questionnaire was designed to collect a selected range of information on individuals covering the types of occupation the women are engaged in, location specific parameters (location of the informal units, visibility of their workplace, distance travelled to their workplace and their mode of travel). The analysis of the data is based on percentages and simple cross tabulations, presenting empirical evidence to explore the spatial attributes (location specific details) as against the types of occupation the women in urban informal sectors are engaged in.

The sample areas are selected on the basis of income classes. Since there was no economic data at the city level, through discussions with the development and planning authorities and through personal experiences, the income clusters are identified. The identified income clusters are Ganeshguri, Bhangagarh, RGB Road, Japorigog (ward No. 43), Chandmari (ward No. 43), Fancy Bazar (ward no.30) Silpukhuri and Ulubari (ward No. 36), which are considered as the high income locality. Hengrabari (ward No. 50), Beltola (ward No. 56), Maligaon (ward no. 5), Bamunimaidan (ward no. 47), Rehabari (ward no. 32), Uzanbazar (ward no. 34), Hedaytpur, Chenikuthi, Kharguli (ward no. 35), SixMile, Khanapara, Panjabari and Satgaon (ward no. 54) are identified as middle income locality. The slum areas of Paltanbazar (ward no.31); Santipur (ward no.18) and Hatigaon (ward no. 58) are identified as the low-income locality. Therefore, there are 15 localities in total.

The household data of women in informal sectors are analysed through women in labour market specifying the type of occupation in informal sectors as classified by ILO (2000), their nature and type of work performed, space and time of work performed relating to work timings, distance travelled to their workplace from their place of residence, mode of transport, amount spent for travelling, number of workplaces and visibility of workplace.

\section{Overview: Types of Occupation of Women in Urban Informal Sectors}

In this section, the occupations of the women in urban informal sectors are analysed. Here, the occupations of the women are based on a revised International Standard Classification of Occupations (ISCO-88) prepared by the Bureau of Statistics of the International Labour Office (ILO, Geneva: 2000).

Women, particularly in Guwahati are principally engaged in the urban informal sector in traditional home-based occupations such as textiles and garment trades (cutting and 
stitching clothes, embroidery works), printing trades, food preparation trades (cutting and cooking vegetables, food stalls), skilled trades (handicrafts), healthcare trades (adult care givers), childcare trades (baby-sitters), leisure services (hairdressers), sales assistants and retail cashiers, elementary construction service, elementary cleaning occupation, elementary personal service occupation (housemaids, washerwoman) and elementary sales occupation (petty hawkers and vendors).

For an easier understanding, the occupations in textile, printing \& food processing are clubbed together under Skilled and Personal services, while construction and sales are combined under Skilled Trades and Elementary Services.

\section{Women in Informal Sectors in Urban Space}

Geography concerns spatial distributions and relationships. Distributions refers to how populations, activities and phenomena are 'dotted' around space such that some areas enjoy huge concentrations (surpluses) while others are marked by scattered land scantiness (deficits, shortages). Spatial relationships imply that places in a given geographical space are infused together by some forces (visible or invisible) which ensure that there is interaction (Light, 2004; Small and Witherick, 1986). Transport (as epitomised in three aspects of the 'way', 'rolling stock' and 'terminal') makes spatial interaction a liveable reality. So is the advancement of information technologies specifically telegraphy, cellular phones, videoconferencing, internet, worldwide web etc. (Light, 2004; Small and Witherick, 1986). Therefore, in Guwahati city, the major informal sector units locate themselves strategically near work centres, commercial areas, outside the boundaries of schools, colleges and hospitals, transport modes and near large housing clusters. Urban informality is an urbanisation mode that connects various economic activities and space in urban areas. Since human activities take place in space, there is a high demand for urban public land and spaces for the accommodation of the evergrowing needs of the informal sector, both to settle and to trade.
Informal sector operations in the urban sphere of Guwahati, like in any other developing countries, continue to rise tremendously. The chief reason for the growth of this sector is due to high urban unemployment rates and consequential urban poverty. In this section, the occupations of the women in urban informal sectors against space/ location is analysed by identifying three basic forms of informal sector activities, viz., the neighbourhood-based, those that take place in industrial sites or in their vicinity and those that take place in the central business district (CBD). The neighbourhood-based operations take place nearer home. It is somewhat residencetied. Examples include women who sell vegetables alongside the street pavements in different residential areas of urban centres. Those informal sector activities that take place in industrial sites or in their vicinity are those women that either walk from their homes or they may travel by motorised transport from distant suburbs. The market of commodities is the employees in industrial firms. Activity is drawn by the clientele. Operators in the informal sector are attracted to the central business district because of the many advantages that it enjoys relative to other parts of a town. In the CBD, the items sold are of a diverse kind; operators take advantage of diverse mix of the threshold supporting the goods and services on offer. Those who operate with licenses, and in designated points, are usually safer than those without, and who are often subjected to police harassment (Chirisa, 2009; Hlohla, 2008).

\section{Spatial Distribution of Urban Informal Sectors}

In this study, the city is divided into four zones:

1. West Guwahati: ward no.5 (Maligaon) and ward no. 18 (Santipur)

2. Central Guwahati: ward no. 30 (Fancy Bazaar), ward no. 31 (Paltan Bazaar), ward no. 32 (Rehabari), ward no. 34 (Uzan Bazaar) and ward no. 35 (Hedaytpur/ Chenikuthi/ Kharguli)

3. East Guwahati: ward no. 36 (Silpukhuri), ward no. 37 (Chandmari), ward no. 47 
(Bamunimaidan) and ward no. 50 (Hengrabari),

4. South Guwahati: ward no. 43 (Ganeshguri), ward no. 54 (Six Mile), ward no. 56 (Beltola) and ward no. 58 (Hatigaon).

The

spatial

distribution

of unorganised/informal services is concentrated nearer to the central business areas of Guwahati rather than the neighbourhoodbased. Since the informal sector is highly demand dependent and such demands are in the central business areas of the city, the informal sector thrives best in CBDs. Consequently, instead of being pushed out because of lack of physical space, it optimises the space and remains competitive due to low overhead costs.
The location-specific informal services (Table $1)$, i.e. for skilled services (33.30 \%) and for elementary service (35.90\%), are physically and optimally accommodated in these central areas of Guwahati city (Fancy Bazaar, ward no. 30; Paltan Bazaar, ward no. 31; Rehabari, ward no. 32; Uzaan Bazaar, ward no. 34 and Hedaytpur/ Chenikuthi/ Kharguli, ward no. 35) followed by the surrounding areas (Silpukhuri, Chandmari, Rehabari, Ulubari/ South Sarania) of eastern part of Guwahati city - for the skilled services $(35.60 \%)$ and for elementary service (21.80 \%). In the west zone, the skilled and elementary services are very less (2.30\% and $17.40 \%)$, respectively.

Figure 1 Map of Guwahati

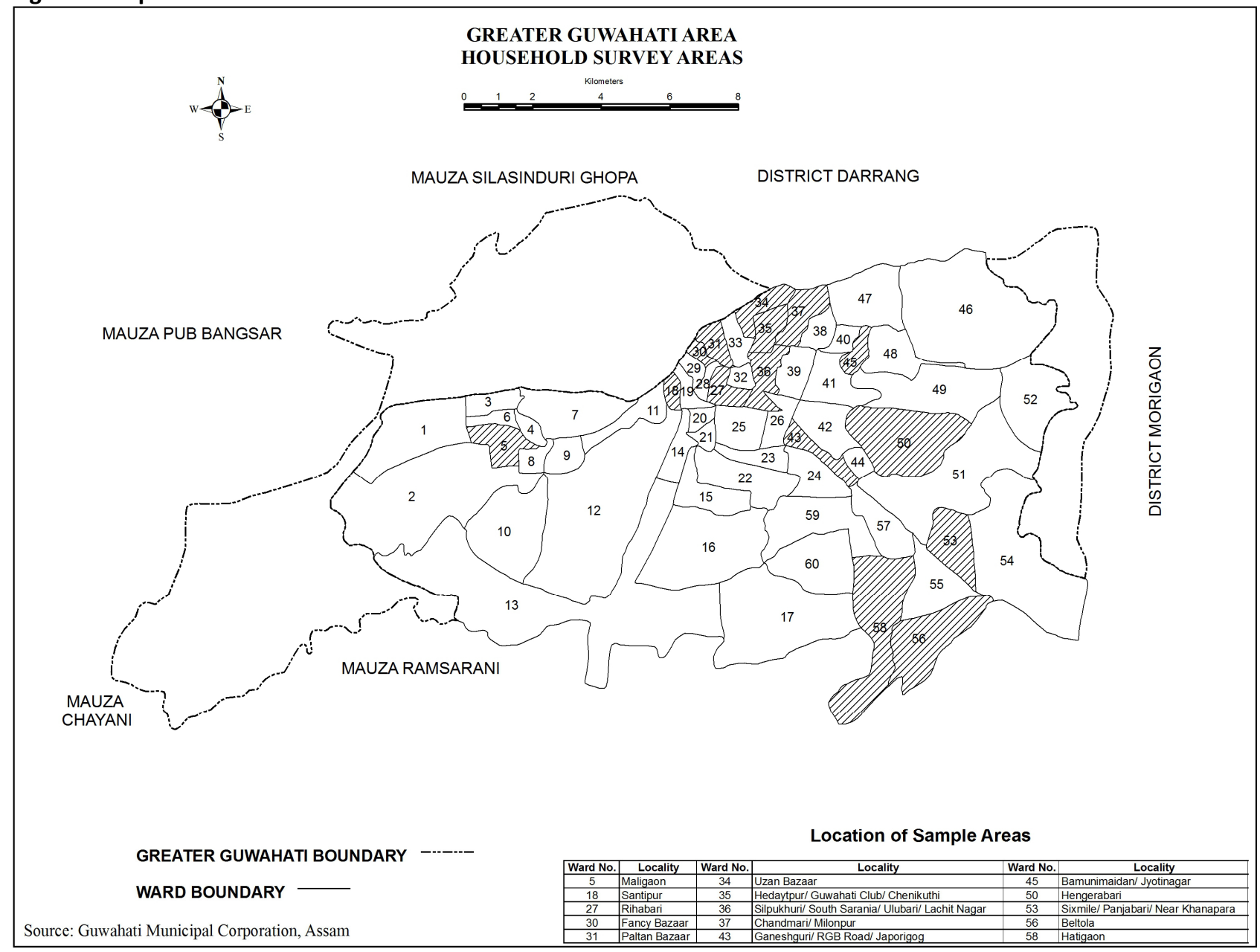


Table 1 Percentage of Women by Spatial Distribution of Wards (Guwahati city) and Type of Occupation (Minor Group)

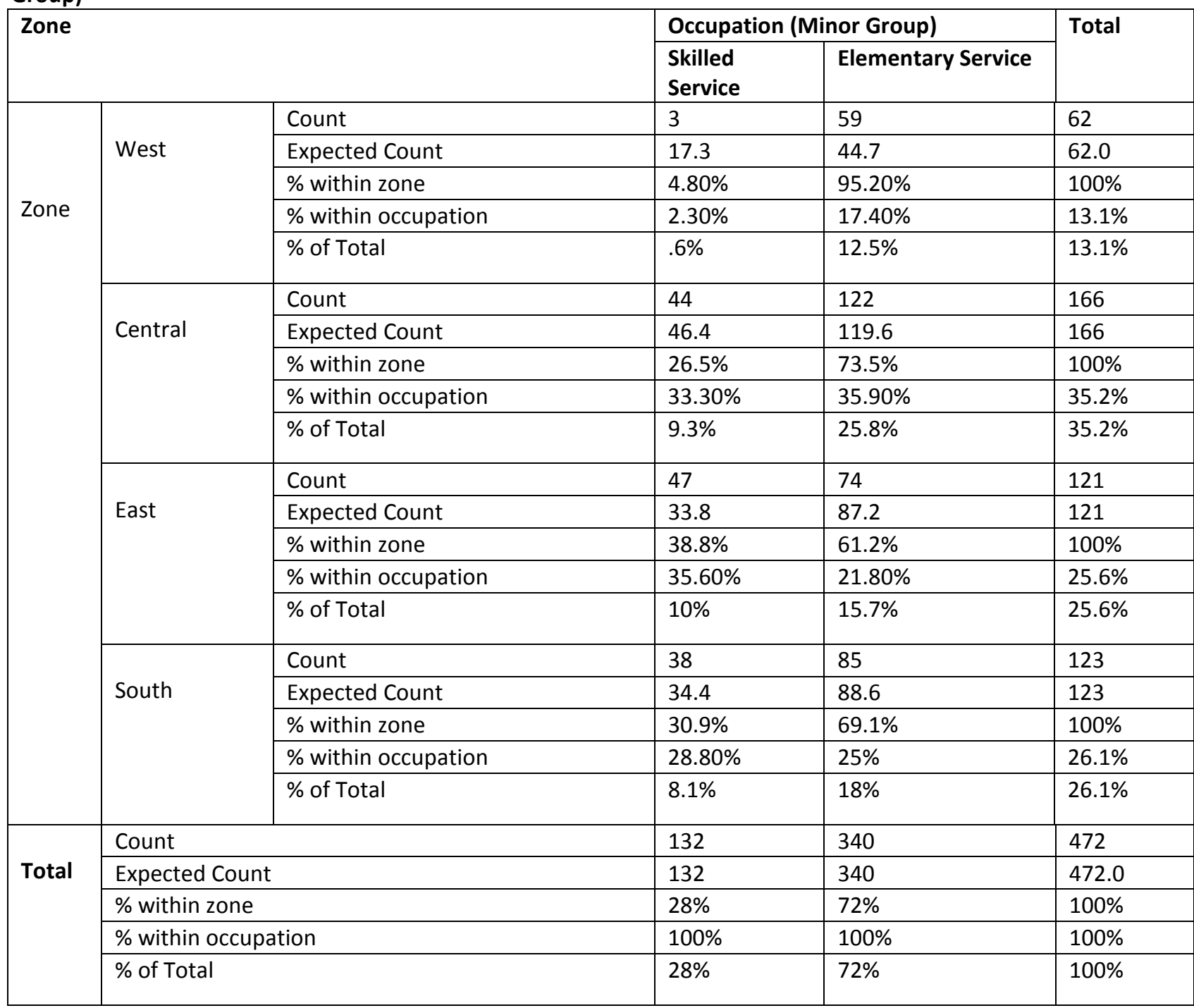

Source: Based on Field Work, 2008-09

\section{Occupation and Visibility of Workplace}

It is apparent from Table 2 that over two-thirds of the women (67\%) engaged in textiles, printing and skilled services (textiles and garments) works from their home. That is, women in these services are predominantly home based production services. Again, majority of the women (75\%) working in the textiles, printing and food preparation and skilled services, operate from their backyards. Similarly, over two-thirds (67\%) of total sampled women functioning from the street pavements are engaged in elementary sales occupation and one-third of them (32\%) are occupied in textiles, printing and skilled services.

Most of the women workers (96\%) in elementary construction and trade services work at the construction sites, while 93\% women employed in elementary personal services (cleaning) work at different households as domestic helpers. All of the women engaged in elementary personal (sales) services work at market places. Similarly, workers employed as textiles, printing and skilled traders work at tailor's shop, while those women engaged in leisure services work at beauty parlours. The women engaged in sales related occupation as retail cashiers operate at shops and those occupied in caring personal services work at other places.

Therefore, it is observed that the occupations of the women workers are location-specific, that is, the manufacturing sectors (textiles, food preparation, printing and skilled service) are mainly home/shop based production (fixed 
locations) whereas the service sectors (leisure, caring, elementary construction, elementary sales and cleaning occupation) operate at variable locations (construction sites, street pavements, marketplaces and other various locations).

\section{Occupations and Distances to Workplace}

Of the total 500 respondents sampled for the survey, more than half $(58 \%)$ of the respondents have to travel in between 1 to 5 kms to their workplace; 26\%, in between 101 metres to $1 \mathrm{~km}$; $10 \%$, for more than $5 \mathrm{~km}$ and the rest (7\%) has to travel for less than 100 metres (Table 3).

It is observed (Figure 2) that, as regards travel distance from home to workplace, more than half of the respondents both in skilled services $(58 \%)$ and in elementary personal services (57\%) have to travel between 1 kilometre to 5 kilometres because most of the services in informal services thrives in central business areas of Guwahati city as mentioned in Table 1.

Table 2: Percentage of Women by Occupation (Sub Group) and Visibility of Workplace

\begin{tabular}{|c|c|c|c|c|c|c|c|}
\hline \multirow{2}{*}{$\begin{array}{l}\text { Visibility of } \\
\text { Workplace }\end{array}$} & \multicolumn{6}{|c|}{ Occupation - Sub Group (\%) } & \multirow{2}{*}{$\begin{array}{l}\text { Total } \\
\text { (\%) }\end{array}$} \\
\hline & $\begin{array}{l}\text { Textiles, } \\
\text { Printing, } \\
\text { other } \\
\text { skilled } \\
\text { trades } \\
(\mathrm{N}=131)\end{array}$ & $\begin{array}{l}\text { Caring, } \\
\text { Personal } \\
\text { Service } \\
(\mathrm{N}=5)\end{array}$ & $\begin{array}{l}\text { Leisure } \\
\& \text { other } \\
\text { personal } \\
\text { service } \\
(\mathrm{N}=16)\end{array}$ & $\begin{array}{l}\text { Sales } \\
(N=18)\end{array}$ & $\begin{array}{l}\text { Elementary } \\
\text { trades } \\
\& \\
\text { construction } \\
\text { service } \\
(\mathrm{N}=45)\end{array}$ & $\begin{array}{l}\text { Elementary } \\
\text { personal } \\
\text { service } \\
\text { (cleaning \& } \\
\text { sales) } \\
(\mathrm{N}=284)\end{array}$ & \\
\hline Home & 66.67 & 0.00 & 11.11 & 11.11 & 0.00 & 11.11 & 100 \\
\hline Backyard & 75.00 & 0.00 & 0.00 & 8.33 & 0.00 & 16.67 & 100 \\
\hline On Streets & 31.50 & 0.00 & 0.00 & 1.57 & 0.00 & 66.93 & 100 \\
\hline Office & 0.00 & 0.00 & 0.00 & 100 & 0.00 & 0.00 & 100 \\
\hline People's house & 0.00 & 4.00 & 0.80 & 0.00 & 0.00 & 95.20 & 100 \\
\hline Construction & 0.00 & 0.00 & 0.00 & 0.00 & 95.56 & 4.44 & 100 \\
\hline Variable location & 1.75 & 0.00 & 1.75 & 0.00 & 3.51 & 92.98 & 100 \\
\hline Market place & 0.00 & 0.00 & 0.00 & 0.00 & 0.00 & 100 & 100 \\
\hline Tailor's shop & 100.00 & 0.00 & 0.00 & 0.00 & 0.00 & 0.00 & 100 \\
\hline Parlour & 0.00 & 0.00 & 100 & 0.00 & 0.00 & 0.00 & 100 \\
\hline Shops & 7.14 & 0.00 & 0.00 & 92.86 & 0.00 & 0.00 & 100 \\
\hline Others & 0.00 & 0.00 & 100 & 0.00 & 0.00 & 0.00 & 100 \\
\hline Total & 26.25 & 1.00 & 3.21 & 3.61 & 9.02 & 56.91 & 100 \\
\hline
\end{tabular}

Source: Based on Field Work, 2008-09

Note: $\mathrm{N}$ refers to No. of Observation

Table 3: Percentage of Women by Travel Distance

\begin{tabular}{|l|c|}
\hline Travel Distance & $\begin{array}{c}\text { Percentage 0f } \\
\text { Women }\end{array}$ \\
\hline Less than 100 metres & 6.60 \\
\hline 100 metres -1 kilometres & 25.80 \\
\hline 1 kilometre-5kilometres & 57.80 \\
\hline$>5$ kilometres & 9.80 \\
\hline TOTAL & 100.00 \\
\hline
\end{tabular}

Moreover, due to high rents in the city, the informal workers prefer to stay within the suburbs or in the hilly areas of the city. When each occupation is taken into account, it is seen that women who travel less than 1 kilometre are largely engaged in elementary personal services (sales and cleaning) as it becomes feasible for them to work within a close proximity to reduce spending on travel. We find that very few women in textiles, printing and skilled trades (8\%) travel greater than 5 kilometres and reside near workplace, as they might receive higher pay in textiles, printing and skilled trades. Whereas nearly one-third of the women in elementary personal service (construction sites and sales) who travel greater than 5 kilometres come from the suburbs or the hills as because of high rents inside city.

Therefore, the findings of my research bears significance to the study carried out by Winnie V. Mitullah and Isabella Njeri Wachira (1997) in Nairobi where most of the informal workers lived in the low income areas with a significant proportion living in the informal settlements. The majority of construction workers lived 
within a distance between 0.1 to 3 kilometres from their sites of work. The short distance covered by the construction workers in their journey to work is supported by the mode of transport.

Figure 2: Percentage of Women by Workplace Distance

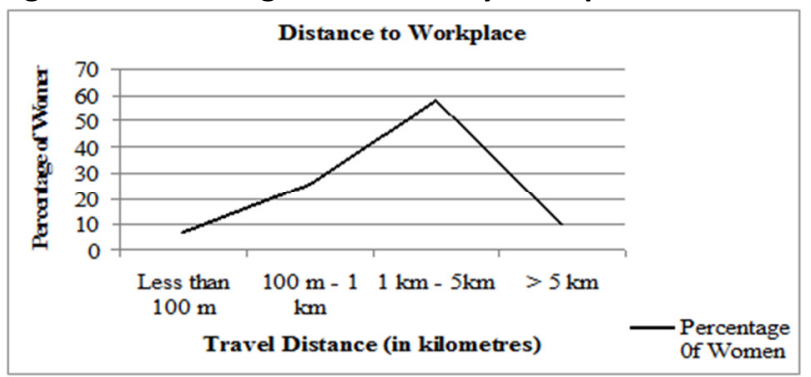

We observe that few women in elementary personal service $(7 \%)$ travel between 1 kilometre to 5 kilometres as they are occupied as housemaids or in elementary sales as they prefer to stay within close proximity from their workplace. Again, more than half of the women in elementary construction (58\%) travel within 1 kilometre to 5 kilometres as construction sites are scattered all over the city, the migrant workers prefer to flock together and prefer to stay on-site or far away for high rents within the city (Table 4). These findings of my research bears resonance to the study carried out by Table 4: Percentage of Women by Workplace Distance and Occupation

\begin{tabular}{|c|c|c|c|c|c|c|c|}
\hline \multicolumn{3}{|l|}{ Occupation } & \multicolumn{4}{|c|}{ Workplace Distance } & \multirow[t]{2}{*}{ Total } \\
\hline & & & $\begin{array}{l}\text { Less than } 100 \\
\text { metres }\end{array}$ & $\begin{array}{l}100 \text { metres } \\
\text { to } 1 \mathrm{~km}\end{array}$ & $\begin{array}{l}1 \mathrm{~km} \text { to } \\
5 \mathrm{kms}\end{array}$ & $\begin{array}{l}\text { More } \\
\text { than } 5 \\
\text { kms }\end{array}$ & \\
\hline \multirow[t]{6}{*}{ Occupation } & \multirow[t]{3}{*}{ Skilled service } & Count & 13 & 38 & 77 & 4 & 132 \\
\hline & & Expected & 7.80 & 35.00 & 76.10 & 13.10 & 132 \\
\hline & & $\begin{array}{l}\text { \% within } \\
\text { service }\end{array}$ & $9.80 \%$ & $28.80 \%$ & $58.30 \%$ & $3 \%$ & $100 \%$ \\
\hline & \multirow{3}{*}{$\begin{array}{l}\text { Elementary } \\
\text { service }\end{array}$} & Count & 15 & 87 & 195 & 43 & 340 \\
\hline & & Expected & 20.20 & 90.00 & 195.90 & 33.90 & 340 \\
\hline & & $\begin{array}{l}\text { \% within } \\
\text { service }\end{array}$ & $4.40 \%$ & $25.60 \%$ & $57.40 \%$ & $12.60 \%$ & $100 \%$ \\
\hline \multirow{3}{*}{ Total } & \multicolumn{2}{|l|}{ Count } & 28 & 125 & 272 & 47 & 472 \\
\hline & \multicolumn{2}{|l|}{ Expected Count } & 28 & 125 & 272 & 47 & 472 \\
\hline & \multicolumn{2}{|l|}{ \% within service } & $5.90 \%$ & $26.50 \%$ & $57.60 \%$ & $10 \%$ & $100 \%$ \\
\hline
\end{tabular}

Source: Based on Field Work, 2008-09

Note: $\mathrm{km} / \mathrm{kms}$ : kilometre/s

Note: $\mathrm{N}$ refers to No. of Observations spatial explanation to occupational segregation of women bears connection to women's routinised mobility to work patterns.

\section{Occupations by Mode of Travel to Workplace}

Table 5 clearly exhibits that over two-thirds of women who travel on foot to their workplace are engaged in elementary personal (particularly in cleaning) services. Again, onethird of women in elementary personal service $(30.12 \%)$ and in textiles, printing and other skilled trades $(32.53 \%)$ travel by city bus to their place of work. A majority of the respondents $(66.67 \%)$ in elementary personal services (particularly in sales) travel by rickshaws to their workplace.

Nearly, one-thirds of total women engaged in textiles, printing and skilled services have either to walk or travel by city bus or rickshaws to their workplace. There is almost an equal distribution of women in elementary construction and personal services that travel by other modes of transport such as trekkers or carriers.
Hanson and Pratt (1995), who argues that 
Bhuyan. Space and Culture, India 2013, 1:1

http://www.spaceandculture.in/index.php/spaceandculture/article/view/21/12

Page 80

Table 5: Percentage of Women by Occupation (Sub Group) and Mode of Travel

\begin{tabular}{|c|c|c|c|c|c|c|c|}
\hline \multirow[t]{2}{*}{ Mode Of Travel } & \multicolumn{6}{|c|}{ Occupation - Sub Group (\%) } & \multirow[t]{2}{*}{ Total (\%) } \\
\hline & $\begin{array}{l}\text { Textiles, } \\
\text { Printing, other } \\
\text { skilled } \\
\text { trades } \\
(\mathrm{N}=131)\end{array}$ & $\begin{array}{l}\text { Caring } \\
\text { personal } \\
\text { service } \\
(\mathrm{N}=5)\end{array}$ & $\begin{array}{l}\text { Leisure } \\
\& \text { other } \\
\text { personal } \\
\text { service } \\
(\mathrm{N}=16)\end{array}$ & $\begin{array}{l}\text { Sales } \\
(N=18)\end{array}$ & $\begin{array}{l}\text { Elementary } \\
\text { trades } \\
\& \\
\text { construction } \\
\text { service } \\
(\mathrm{N}=45)\end{array}$ & $\begin{array}{l}\text { Elementary } \\
\text { personal } \\
\text { service } \\
(\mathrm{N}=\mathbf{2 8 4})\end{array}$ & \\
\hline Walking & 27.75 & 0.58 & 1.73 & 3.18 & 0.58 & 66.18 & 100 \\
\hline City Bus & 32.53 & 2.41 & 12.05 & 8.43 & 14.46 & 30.12 & 100 \\
\hline Rickshaws & 33.33 & 0.00 & 0.00 & 0.00 & 0.00 & 66.67 & 100 \\
\hline Others & 9.38 & 1.56 & 0.00 & 0.00 & 48.44 & 40.63 & 100 \\
\hline TOTAL & 26.25 & 1.00 & 3.21 & 3.61 & 9.02 & 56.91 & 100 \\
\hline
\end{tabular}

Source: Based on Field Work, 2008-09

Note: $\mathrm{N}$ refers to No. of Observations

\section{Conclusion}

The research uses a WID approach to seek women's engagement in the informal sector of greater Guwahati area. The study provides a glimpse into the principal urban informal sectors where women are primarily engaged in and the location of their informal units. However, the most important limitation of this study lies in the fact that it fails to make gender analysis using Gender and Development (GAD) approach. Nevertheless, it adds a new literature to the study of informal sectors (Williams and Gurtoo, 2011) and promotes a direction for further research. The concerns of informal economy workers and particularly women workers can be easily overlooked in the process of policymaking and legislative change. Since the urban space the women informal workers have occupied is not theirs and that government should mitigate plans to encourage the women who are engaged in informal sectors to have urban space for operating the units as it helps both in the economy as well as in welfare of the society.

As such, organisation, representation and social dialogue are valuable means for ensuring that policy development in relation to informal economy takes into account the diversity of interests and especially the different interests of men and women. In recent years, efforts have stepped up in enhancing the organisation and representation of informal economy workers and units through various strategies. Efforts to better understand this phenomenon and a willingness to embrace its possibilities while ameliorating its undesirable effects could lead to innovative plans, affirming that "there is also quite a bit to be learned from what goes wrong" (Roy, 2005: 156)

\section{Acknowledgements}

I am grateful to my supervisor Prof. A.C. Mohapatra, Department of Geography, NEHU, Shillong who has always given me the support and guidance during my study. I would also like to acknowledge with sincere appreciation to the anonymous reviewers for their valuable comments and suggestions to improve my research work.

\section{About the Author}

Zona Bhuyan recently submitted her Ph.D. research work at North Eastern Hill University (NEHU) and is currently waiting for her viva examination. She received the Jawaharlal Nehru Memorial Fund Academic Fellowship to complete her research. Through her research work, she had made a detailed assessment of the well-being of women in urban informal sectors in the metropolitan city of Assam, India. She plans to continue working in development research that focuses on gender issues in South Asian countries. Presently she is working in a GIS consultancy firm in Guwahati.

\section{References}

Abramo, L. and Valenzuela, M.E. (2006). Inserción Laboral y Brechas de Equidad de Género en América Latina, in Laís Abramo (ed.), Trabajo Decente y 36 DEPTSExternal-2008-02-0341-1-En.doc Equidad de Género en América Latina Santiago: Oficina Internacional del Trabajo, pp. 29-62 
Bhuyan. Space and Culture, India 2013, 1:1

http://www.spaceandculture.in/index.php/spaceandculture/article/view/21/12

Page 81

Armstrong, A. and T.G. McGee (1985). Theatres of Accumulation: Studies in Asian and Latin American Urbanization, London: Methuen.

Bhatt, E. (2006). We are Poor but so Many: The Story of Self-employed Women in India, New Delhi: Oxford University Press.

Bhattacharyya Sarma R. (2009). Feminist Political Economy, in Kitchin R, Thrift N (eds) International Encyclopedia of Human Geography, Oxford: Elsevier, 4, pp. $79-86$

Bivens Josh L. and S. Gammage (2004). Will better workers lead to better jobs in the developing work?, in Avirgan Tony, Bivens Josh L. and Gammage Sarah (eds.) Good Jobs, Bad Jobs, No Jobs: Labour Markets and Informal work in Egypt, El Salvador, India, Russia and South Africa, Economic Policy Institute: Washington D.C.

Boserup, E. (1970). Women's Role in Economic Development, New York: St. Martin's Press.

Branea, A.M (2011). Revitalization Strategy of Urban Spaces through a Holistic Vision - Case Study Timisoara, International Journal of Energy and Environment, 1(5), pp. 24

Bromley, R. (2009). Informal Trade and Urban Space in the Third World City, Available at:

http://www.swansea.ac.uk/geography/reserach/socialth eoryand urbanspace/theuseofurbanspace (accessed April 18, 2013).

Carr, M. and M. Chen (2002). Globalization and the Informal Economy: How Global Trade and Investment Impact on the Working Poor, Working Paper on the Informal Economy Working No. 1 INTEGRATION, Geneva: International Labour Office.

Charmes J. (2000). Informal Sector, Poverty and Gender. A Review of Empirical Evidence, World Development Report 2001, Washington: The World Bank, p.44

Charmes, J. (2009). Concepts, Measurement and Trends. In Is Informal Normal? Towards More and Better Jobs in Developing Countries, JP Jütting and JR Laiglesia (eds.). Paris: OECD.

Chirisa, I. (2009). The Geography of Informal Sector Operations (ISOs): A Perspective of Urban Zimbabwe, Journal of Geography and Regional Planning, 2(4), pp. 066-079

Fernández and J. Pacheco (2003a). Género, Pobreza y Mercado de Trabajo para las

Mujeres en Honduras, in Janina Fernández-Pacheco (ed.), Género y Mercado de Trabajo. Honduras y Nicaragua: Proyecto: Género, Pobreza y Empleo en América Latina, San José: Organización Internacional del Trabajo), pp. 43-153

Fernández and J. Pacheco (2003b). Estudio Propositivo sobre la Situación de las Mujeres y los Hombres en el
Mercado de Trabajo en Nicaragua, Género y Mercado de Trabajo. Honduras y Nicaragua: Proyecto: Género, Pobreza y Empleo en América Latina, San José: Organización Internacional del Trabajo), pp. 155-285

Global Employment Trends for Women (2012). International Labour Organisation, Available at: http://www.ilo.org/wcmsp5/groups/public/--dgreports/---dcomm/documents/publication/ wcms_195447.pdf (accessed April, 15, 2013)

Guwahati Metropolitan Development Authority (2006). City Development Plan:Guwahati. Available at http://www.CDP_Guwahati.jnnurm.nic.in (accessed May 12, 2010)

Hakim, C. (1996). Key Issues in Women's Work: Female Heterogeneity and the Polarisation of Women's Employment, London: Athlone.

Hanson, S. and G. Pratt (1995). Gender, Work and Space, London: Routledge.

Hlohla, P. (2008). Examining the Concept and Practice of Economic Participation with reference to the CBD of Harare: A case of the Unemployed Youths (UYs), Department of Rural \& Urban Planning, University of Zimbabwe: Harare, (Unpublished Dissertation).

Human Development Report 1995: Gender and Human Development, Available at http://hdr.undp.org/en/reports/global/hdr1995/ (accessed April 15, 2013)

International Labour Office (1972). Employability in the Global Economy: How Training Matters, World Employment Report, Geneva. Available at http:// www.ilo.org (accessed July 18, 2006)

International Labour Office (1997). Employment, Incomes and Equality. A Strategy for Increasing Productive Employment in Kenya, World Employment Report, Geneva. Available at

http://www.freepatentsonline.com/article/JournalInternational-Business-Economics/208535028.html (accessed March 25, 2013)

International Labour Office (2000). The Revised International Standard Classification of Occupations (ISCO-88), Vol. 1, Geneva.

International Labour Office (2002). Women and Men in the Informal Economy: A Statistical Picture, Geneva: InternationalLabor Office.

Light, I. (2004). Immigration and Ethnic Economies in Giant Cities, in Crowley, John (ed.) Blackwell

Publishing/UNESCO: Paris. Int. Soc. Sci. J. 181

Mathew, P.M. (1989). Urban Informal sector: How it should be understood?, Urban Affairs Quarterly, 4, pp. 57 $-65$

Mazumdar, D. (1976). The Urban Informal Sector, World Development, 4 (8), pp. 35-47 
Bhuyan. Space and Culture, India 2013, 1:1

http://www.spaceandculture.in/index.php/spaceandculture/article/view/21/12

Page 82

Mccann, P. (2001). Urban and Regional Economics, Oxford University Press: Oxford.

McDowell, L. (1992). Doing Gender: Feminism, feminists and research methods in human geography, Transactions of the Institute of British Geographers, 17(4), pp. 399-416

Mitullah.W.V. and I. N. Wachira (1997). Informal Labour in the Construction Industry in Kenya: A Case Study of Nairobi, Available at http://www.ilo.org/wcmsp5/groups/public/@ed_emp/ @emp_policy/@invest/documents/publication/wcms_as ist_8175.pdf (accessed April 18, 2013)

Momsen, J. (1991). Women and Development in the Third World, London: Routledge.

Monk, J., and S. Hanson (1982). On not excluding Half of the Human in Human Geography, The Professional Geographer, 34(1), pp. 11-23

Mupedziswa, R. and P. Gumbo (1998). Structural Adjustment and Women Informal Traders in Harare, Zimbabwe, Almquivist and Wiksell International, Stockholm, Sweden: Motala Grafiska (ISSN: 1104-8425)

Nelson, N. (1988). How Women and Men Get by: The Sexual Division of Labour in the Informal Sector of a Nairobi Squatter Settlement, in J. Gugler (ed.), The Urbanization of the Third World, New York: Oxford University Press, pp. 183-203

Nwaka, G.I. (2005). The Urban Informal Sector in Nigeria; Towards Economic Development; Environmental Health and Social Harmony, Global Urban Development Magazine 1 (1), pp. 1-11

Olsen, T. (1978). Silences, London: Virago.

Perera Ranjith L.A.S (1994). Accommodating Informal Sector Enterprises in the Urban Built - Environment: Introduction, Bangkok: Asian Institute of Technology, pp. $1-14$

Quijano-Obregon, A. (1974). The Marginal Pole of the Economy and The Marginalized Labour Force, Economy and Society, 6(1): pp. $393-428$

Roy, A. (2005). Urban Informality: Toward an Epistemology, Journal of the American Planning Association, 71: 2, pp.147-158

Roy, A. and N. AlSayyad (2004). Urban Informality: Transnational perspectives from the Middle East, South Asia and Latin America, Lanham, MD: Lexington Books.

Ray, B.D. and G. Das (2006). Informality and Poverty: Urban Landscape of India's North-East, Akansha: India.

Sethuraman, S.V. (1981). The Urban Informal sector in Developing Countries: Employment Poverty and Environment, Geneva: ILO, p. 173

Shram Shakti-A Report of the National Commission on Self-Employed Women in the Informal Sector (1988).
Department of Women and Child Welfare, Government of India.

Small, J and M. Witherick (1986). A Modern Dictionary of Geography (Third Edition), Arnold: London.

Standing, G. (1999). Global Feminization through Flexible Labor: A Theme Revisited, World Development, 27(3), pp.583-602

Todaro, M. (1969). A Model of Labour Migration and Urban Employment in Less Developed Countries, New York: Plenum.

Unni, J. and U. Rani (2000). Women in Informal Employment in India, Paper presented at the International Association for Feminist Economics 2000 Conference, Bogazici University, Istanbul, Turkey, 15th 17 th

Vega Gramunt, L. (2004). Género en la Crisis Argentina: Análisis del Impacto y Estrategias de Respuesta 20012003, Working Paper No.14. In Focus Programme on Crisis Response and Reconstruction, Geneva: International Labour Office.

Watson, V. (2011). Inclusive Urban Planning for the Working Poor: Planning Education Trends and Potential Shifts in Women in Informal Employment: Globalizing and Organizing (WIEGO) Urban Policies Research Report, No 11, Available at:

http://wiego.org/sites/wiego.org/files

/publications/files/ Watson -Inclusive-Urban-Planning. pdf (accessed February 26, 2013)

Williams, C.C. and A. Gurtoo (2011). Evaluating Women Entrepreneurs in the Informal Sector: Some evidence from India, Journal of Developmental Entrepreneurship, 16 (3), pp. 351-369

Young, K. (1981). Women and the Informal Sector, Special Issue of Bulletin of the Institute of Developmental Studies, 10, pp. 3-4 